\title{
Telaahan Kerjasama Pemerintah Swasta Dalam Pembangunan Bandara Kertajati Di Jawa Barat
}

\author{
Andiyan, Agus Rachmat \\ Program Studi Arsitektur Fakultas Sains dan Teknik Universitas Faletehan \\ andiyanarch@gmail.com
}

Received: 12 Januari 2021; Revised: 26 Februari 2021; Accepted: 28 April 2021 DOI: http://dx.doi.org/10.37905/aksara.7.2.413-424.2021

\begin{abstract}
Abstrak
Bandara Internasional Jawa Barat (BIJB) Kertajati di Kabupaten Majalengka dijadwalkan akan mulai beroperasi pada Maret 2018 mendatang. Saat ini progres pembangunan sudah hampir menyentuh angka 50\%. Direktur Pengembangan Bisnis dan Investasi BIJB Kertajati saat ini pyoyek pembangunan bandara seluas 1.800 hektar dan aerocity 3.490 hektar pertanggal 23 Juli 2017 sudah mencapai 49,7898 \%. Progres paket satu atau pekerjaan infrastruktur sudah mencapai 84,9452 persen. Paket kedua atau terminal utara penumpang mencapai 33,2087 persen. Dan paket ketiga atau bangunan penunjang operasional mencapai 75,5038 persen. Pihaknya optimistis jika pembangunan fisik yang ditargetkan selesai pada November-Desember 2017 akan terkejar. Untuk mempercepat terutama dari segi detail finalisasi terminal pihaknya berencana menambah Sumber Daya Manusia (SDM). Sehingga progres pembangunan akan tepat waktu. Dari segi aksesibilitas calon penumpang pihaknya juga optimistis tidak akan terkendala. Pasalnya saat ini sudah ada Tol Cipali yang akan segera tersambungkan hingga ke area bandara. Belum lagi rencananya tahun 2019 ruas Tol Cisumdawu selesai. Itu akan mempermudah akses kita.
\end{abstract}

Kata Kunci: Bandara Internasional Jawa Barat (BIJB) Kertajati, Kabupaten Majalengka,infrastruktur, Tol Cisundawu

\begin{abstract}
West Java International Airport Kertajati in Majalengka Regency is scheduled to start operating in March 2018. Currently, the progress of development has almost reached $50 \%$. Director of Business Development and Investment of BIJB Kertajati currently has an airport construction project of 1,800 hectares and an aerocity of 3,490 hectares as of 23 July 2017 has reached $49.7898 \%$. The progress of package one or infrastructure work has reached 84.9452 percent. The second package or the north passenger terminal reached 33.2087 percent. And the third package or operational support buildings reached 75.5038 percent. He is optimistic that the physical construction which is targeted for completion in November-December 2017 will be overtaken. To speed up, especially in terms of the details of terminal finalization, his party plans to add Human Resources (HR). So that development progress will be on time. In terms of accessibility, prospective passengers are also optimistic that they will not be constrained. The reason is that currently there is a Cipali Toll Road which will soon be connected to the airport area. Not to mention the plan for the completion of the Cisumdawu toll road in 2019. It will
\end{abstract}


make our access easier. Keywords: West Java International Airport (BIJB) Kertajati, Majalengka Regency, infrastructure, Cisundawu Toll Road

\section{PENDAHULUAN}

Pencapaian Indikator Kinerja Daerah (IKD) pada Misi Keempat terhadap penyelenggaraan urusan Pemerintahan Provinsi Jawa Barat untuk Bidang Perhubungan adalah tingkat ketersediaan fasilitas perlengkapan jalan Provinsi sebesar 20,03\% pada Tahun 2016 dengan sasaran Meningkatnya percepatan pembangunan infrastruktur strategis. Selain itu pencapaian juga dilihat dari penyelesaian pembangunan BIJB Kertajati dan Bandara Nusawiru,ketersediaan prasarana pada Angkutan Sungai, Danau, dan Penyeberangan (ASDP) di Jawa Barat, serta ketersediaan sarana dan prasarana pemeriksaan kendaraan bermotor. Capaian kinerja Bidang Perhubungan tersebut dicapai melalui program dan kegiatan sebagai berikut.

Program Pembangunan Prasarana dan Fasilitas Perhubungan Program Pembangunan Prasarana dan Fasilitas Perhubungan Program Pembangunan Prasarana dan Fasilitas Perhubungan memiliki indikator yaitu : 1) Tingkat ketersediaan prasarana transportasi udara penyelesaian pembangunan BIJB Kertajati dan Bandara Nusawiru yang meningkat menjadi 51,90\% pada Tahun 2016; 2) Tingkat ketersediaan prasarna transportasi ASDP dan pelabuhan pengumpan regional Jabar Selatan yang meningkat menjadi 69,69\% pada Tahun 2016; dan 3) Ketersediaan prasarana jalur kereta api di Jawa Barat, yang mencapai $1.135,44 \mathrm{Km}$ pada Tahun 2016. Program ini dilaksanakan oleh Dinas Perhubungan Provinsi Jawa Barat melalui 29 (dua puluh sembilan) kegiatan dengan total alokasi anggaran Rp.44.976.047.200,- dengan realisasi anggaran Rp.27.877.928.292,- atau 62,60\%. Outcomes program adalah 1) Meningkatnya kesesuaian besaran organisasi dengan beban kerja; 2) Meningkatnya perolehan nilai hasil evaluasi penerapan SAKIP; 3) Terwujudnya penegasan batas daerah dan kode Wilayah; 4) Terselenggaranya pelayanan publik yang bermutu dan akuntabel di seluruh tingkatan pemerintahan daerah; 5) Terwujudnya kinerja pelayanan pemerintah sesuai harapan masyarakat Permasalahan penyelesaian program adalah (1) Kegiatan Proses Sertifikasi Tanah Pengganti Tanah Kas Desa yang dipakai Bandara Nusawiru, kegiatan adalah masih menunggu proses sertipikat dari pihak BPN Kabupaten pangandaran; (2) Kegiatan Sinergitas Pembangunan dan Pengembangan Bandar Udara di Jawa Barat, dengan adanya rencana pengambil alihan pembangunan BIJB secara keseluruhan, berimplikasi terhadap berubahnya rencana program koordinasi dan konsolidasi dengan seluruh stake holder yang terlibat dalam pembangunan BIJB; (3) Kegiatan Pembangunan Gedung Display BIJB di Kertajati, Pembangunan Gedung Display Tahap I baru mencapai $25,69 \%$ dikarenakan pada saat pelaksanaan terjadi curah hujan Selama 2 (dua) bulan yang mengakibatkan pekerjaan terhenti dan ketika akan melakukan addendum waktu tidak mencukupi; (4) Kegiatan METR Penanganan Dampak Sosial dan Persiapan Pembebasan Lahan Reaktivasi Jalur Kereta Api RancaekekTanjungsari dan Banjar - Pangandaran - Cijulang, kegiatan adalah terdapat belanja jasa profesi yaitu honorarium untuk personil Kabupaten/kota (TNI/POLRI/PNS non Provinsi dan lain-lain) dalam rangka penertiban/pengadaan 
lahan dijalur reaktivasi Rancaekek - Tanjungsari dan Banjar-PangandaranCijulang, namun dikarenakan pada Tahun 2016 kegiatan penertiban lahan yang seharusnya dimotori langsung oleh PT. KAI tidak mengangarkan untuk kegiatan penertiban lahan, sehingga jasa belanja profesi tersebut pun tidak terserap. Program Rehabilitasi dan Pemeliharaan Prasarana dan Fasilitas Lalu Lintas Angkutan Jalan (LLAJ) Program Rehabilitasi dan Pemeliharaan Prasarana dan Fasilitas Lalu Lintas Angkutan Jalan (LLAJ) memiliki indikator yaitu tingkat ketersediaan fasilitas perlengkapan jalan (rambu, marka,dan guardrill) dan penerangan jalan umum (PJU) pada jalan provinsi, yang meningkat menjadi 20,03\% pada Tahun 2016.Program ini dilaksanakan oleh Dinas Perhubungan Provinsi Jawa Barat melalui 6 (enam) kegiatan dengan total alokasi anggaran Rp.12.797.147.084,- dengan realisasi anggaran Rp.10.188.536.406,- atau 79,62\%. Outcomes program adalah meningkatnya kualitas prasarana dan fasilitas LLAJ (menuju zero accident) melalui peningkatan ketersediaan fasilitas perlengkapan jalan di ruas jalan Provinsi dan pengembangan informasi teknologi untuk mengatasi persoalan lalu lintas jalan.Permasalahan pelaksanaan program adalah Kegiatan METR Pengembangan Fasilitas Lalu Lintas Jalan di Wilayah Metropolitan Bandung, Pekerjaan Pengadaan dan Pemasangan PJU gagal lelang dan kegiatan akan dianggarkan kembali Tahun 2017. Program Peningkatan Pelayanan Angkutan Program Peningkatan Pelayanan Angkutan memiliki indicator yaitu tingkat pelayanan angkutan di jaringan jalan provinsi yang meningkat menjadi 94\% pada Tahun 2016. Program ini dilaksanakan oleh Dinas Perhubungan Provinsi Jawa Barat melalui 6 (enam) kegiatan dengan total alokasi anggaran Rp.3.244.325.000,-, dengan realisasi anggaran Rp.2.263.705.316,-, atau $69,77 \%$. Outcomes program adalah 1) Berkembangnya sistem transportasi publik regional yang nyaman; 2) Berkembangnya terminal angkutan umum regiona 1 yang terpadu dan modern; 3) Meningkatnya kesadaran berlalu lintas dan kinerja awak kendaraan umum; 4) Meningkatnya pelayanan perijinan dan pengawasan angkutan umum; 5) Tertatanya jaringan lalu lintas angkutan barang dan penumpang; 6) Meningkatnya kinerja kualitas angkutan umum Antar Kota Dalam Provinsi (AKDP) dan Antar Kota, Antar Provinsi (AKAP) di Jawa Barat, melalui pengembangan terminal angkutan umum regional yang terpadu dan modern, antara lain penyediaan Terminal Tipe A di Kota Bogor, Kota Depok, Kabupaten Bekasi, Kabupaten Karawang, Kota Cirebon, Kota Tasikmalaya, Kota Sukabumi, Kota Bandung dan Kabupaten Bandung; serta penyediaan Terminal Tipe B di Kabupaten Kuningan, Kabupaten Indramayu, Kabupaten Garut, Kota Cimahi, dan Palabuhanratu. a. Pelaksanaan Progra $\mathrm{m}$ 1. Kegiatan Evaluasi Angkutan Penumpang Umum AKDP di Jawa Barat Kegiatan ini dilaksanakan oleh Dinas Perhubungan Provinsi Jawa Barat.Permasalahan pelaksanaan program adalah (1) Kegiatan Evaluasi Manajemen dan Rekayasa Lalu Lintas dan Analisa Dampak Lalin di Jawa Barat, Rapat forum LLAJ disediakan untuk dilaksanakan sebanyak 5 kali namun karena isu (taksi online dan sistem teknologi informasi angkutan umum orang) yang berkembang di Tahun 2016 hanya 2 kali, maka forum LLAJ dilaksanakan hanya 2 kali dan Survei- Survei tidak dapat dilaksanakan karena waktunya bersamaan dengan penyelenggaraan Pekan Olahraga Nasional (PON) 
dan PEPARNAS, dikhawatirkan hasilnya tidak akurat; (2) Kegiatan Evaluasi Angkutan Penumpang Umum AKDP di Jawa Barat,

\section{TUJUAN PENELITIAN}

Kajian ini ditujukan untuk menyusun Pemerintah Provinsi Jawa Barat memutuskan tetap mempertahankan porsi saham mayoritas dalam perubahan skema kepemilikan Bandara Internasional Jawa Barat (BIJB) Kertajati, Majalengka. Memutuskan rencana kerja sama operasi (KSO) antara AP II dengan BUMD PT BIJB diubah menjadi pembentukan badan usaha baru. Konsekuensinya, kepemilikan BIJB Kertajati berubah, karena AP II didorong untuk ikut menanamkan modal sesuai dengan target kerja sama dengan AP II seperti apa skemanya, supaya semua feasible dan menguntungkan.

\section{PEMBAHASAN}

Masalah yang diteliti adalah analisis dampak sosial ekonomi dan politis dalam proses pembangunan bandara udara kertajati di Kabupaten Majalengka, sebagaimana diketahui bersama bahwa pembangunan bandara ini berada di wilayah Desa Kertajati, Desa Bantarjati, dan Desa Kertasari serta Desa Sukamulya di kawasan Kecamatan Kertajati Kabupaten Majalengka yang dirasa belum optimal dalam proses pembangunannya. Penelitian ini bertujuan untuk mengembangkan konsep dan pemikiran akademis bagi Provinisi Jawa Barat dalam merancang kebijakan yang tepat untuk keberlangsungan proses pembangunan bandara di kertajati sehingga dalam proses pembangunannya akan memberikan nilai manfaat lebih bagi masyarakat yang ada di sekitar pembangunan lokasi bandara. Penelitian ini akan menggunakan metode deskriptif dengan pendekatan kualitatif untuk mendalami makna dari satu fenomena yang terjadi. Teknik pengumpulan data dilakukan dengan wawancara mendalam, observasi partisipatif, dokumentasi, serta triangulasi, sehingga dapat diperoleh data dan informasi yang mendukung tujuan studi.

Pembangunan Bandara Kertajati bersama-sama antara Kementerian Perhubungan dan Pemerintah Provinsi Jawa Barat didukung beberapa investor swasta. Kemenhub membangun sisi udara seperti pembangunan landas pacu (runway), area parkir pesawat (appron), jalur pesawat (taxi way), pagar pengaman sekeliling bandara dan sebagainya. Sementara, sisi darat dibangun oleh PT. BIJB yang merupakan perusahan gabungan yang dimiliki Pemerintah Provinsi Jabar dengan investor swasta dengan porsi 51 persen Pemprov Jabar dan 49 persen swasta. Sisi darat yang dibangun adalah terminal utama penumpang, dan infrastruktur pendukung lainnya.

Bandara Kertajati memiliki lahan seluas 1000 Hektar yang pembebasannya telah selesai dilakukan oleh Pemprov Jabar, dan akan dilanjutkan pembebasan lahannya hingga 1800 hektar. Pembangunan sisi darat yang dilakukan PT. BIJB terbagi dalam tiga paket. Paket pertama, yaitu pekerjaan infrastruktur dengan target penyelesaian Juli 2017. Paket kedua, yaitu terminal utama penumpang dengan target penyelesaian November 2017. Paket ketiga, yaitu bangunan penunjang operasional dengan target penyelesaian Agustus 2017. Sementara 
pembangunan di sisi udara yang dilakukan Kemenhub, saat ini sudah terbangun runway sepanjang $2500 \times 60 \mathrm{~m} 2$. taxiway, dan appron $432 \times 98 \mathrm{~m}$, menggunakan dana APBN sebesar 575 milyar rupiah tahun anggaran 2013 sampai dengan 2016. Pada tahun 2017 ini, Kemenhub mengalokasikan anggaran lagi sekitar 250 miliar rupiah untuk melanjutkan pembangunan sebagai persiapan operasi secara minimum yaitu pembangunan pagar pengaman sekeliling bandara dan perimeter, RESA, Stop way, Pave shoulder, Sodding, Rigid, verifikasi kalibrasi, dan sertifikasi.

Nantinya bandara ini akan dibangun dengan luas terminal mencapai 121.100 meter persegi (m2). Namun tahap awal pengoperasiannya, akan dibangun seluas $96.000 \mathrm{~m} 2$ terlebih dahulu yang bisa menampung 5 juta sampai dengan 11 juta penumpang per tahun. Bandara ini mampu didarati pesawat berbadan lebar jenis B747 dan B777.

Kedepan, bandara Internasional Kertajati akan berkonsep Aerotropolis yaitu suatu konsep pengembangan kota bandara atau "Airport City".

Bandara Kertajati di Majalengka diproyeksikan menjadi pusat layanan logistik untuk Jawa Barat dan Jawa Tengah. Untuk mewujudkannya, pemerintah mendorong penyelesaian pembangunan jalan tol ke bandara itu. Kita akan mendorong pembangunan jalan tol Cisumdawu dan koneksinya ke jalan tol Cipali yang menjadi akses penopang menuju bandara ini.

Pembangunan Bandara Internasional Jawa Barat (BIJB) Kertajati, Majalengka diusulkan memakai skema proyek kerjasama pemerintah swasta (KPS) untuk mempercepat berdirinya bandara tersebut.

Kepala Pusat Pengelolaan Risiko Fiskal, Badan Kebijakan Fiskal Kementerian Keuangan Freddy $\mathrm{R}$ Saragih mengatakan dalam waktu dekat pihaknya akan mengunjungi Bupati Majalengka untuk membicarakan secara kongkrit pembiayaan megaproyek tersebut dengan skema KPS. Skema ini diusulkan terkait kesiapan Majalengka menyediakan lahan bagi para investor yang tertarik membangun bandara tersebut. Bupati bilang lahan siap berapapun, artinya 40\% skema KPS sudah selesai karena lahan sudah siap. Kabag Perencanaan Direktorat Perhubungan Udara Kementerian Perhubungan Bintang Hidayat pun menyarankan agar pembangunan airport dan aero city Kertajati memakai skema KPS.

Kertajati adalah salah satu proyek nasional yang kita harapkan sudah jadi paling lambat pertengahan 2018. Bisa digunakan untuk pesawat kelas 747 dan 777, salah satunya untuk memenuhi pangsa besar di Jawa barat yaitu kegiatan Umroh. Kalau sekarang kan kasihan, jamaah umroh dari Jawa Barat dan sekitarnya harus memakan waktu yang cukup lama untuk menuju bandara Soekarno Hatta.

\section{Progres Pembangunan Bandara internasional Kertajati}

Progres pembangunan Bandara Internasional Jawa Barat (BIJB) yang terletak di daerah Kertajati, Kabupaten Majalengka, Jawa Barat telah mencapai hampir $70 \%$. Bahkan pembangunan sarana penunjang operasional Bandara telah mencapai 89\%. Pengerjaan proyek BIJB sudah mencapai 60,8\% per 17 September. Pembangunan terminal penumpang penyelesaiannya telah mencapai 
$43 \%$ dan bangunan penunjang operasioanl bandara telah mencapai $89 \%$. yang berada di lahan seluas 1,800 hektare ini digagas sejak tahun 2003, namun pembangunannya baru intensif dikerjakan sejak dua tahun lalu. Pembangunan BIJB menggunakan skema kerjasama Pemerintah-Swasta (Public Private Partnership). Skema kerja sama ini baru yang pertama kali digunakan dalam pembangunan bandara di Indonesia. BIJB, BUMD bentukan pemerintah provinsi, juga mencari pendanaan dari investor swasta dan perbankan. Sejauh ini Bandara Kertajati sudah mendapatkan pendanaan dari sindikasi bank syariah sebesar Rp906 miliar, peluncuran reksa dana penyertaan terbatas (RDPT), dan PT Angkasa Pura II sebagai calon operator serta investor pembangunan bandara ini.

Mobilitas penduduk dan pergerakan barang serta jasa dari dan menuju Bandungmelalui jalur udara yang cukup tinggi dapat menimbulkan permasalahan transportasi. Permasalahan tersebut timbul diantaranya karena keterbatasan kapasitas dan aksesibilitas (baik penumpang maupun kargo) dari bandara eksisting yaitu bandara Husein Sastranegara-Bandung, lokasi yang berada di tengah kota dan berdekatan dengan gedung perkantoran serta peruntukan awal bandara sebagai bandara militer dan bukan bandara komersial. Oleh karenanya Pemerintah Provinsi Jawa Barat dalam RPJMN 2013-2018 merencanakan pembangunan proyek strategis kawasan bandara berskala Internasional Kertajati di Majalengka. Pembangunan kawasan bandara direncanakan terintegrasi dengan kawasan aerocity yang mencakup pemukiman, industri, perdagangan, perhotelandan kawasan penunjang lainnya (Gambar 1).Tujuan yang ingin dicapai dari pembangunan dan pengembangan kawasan ini adalah:

a. Meningkatkan pertumbuhan ekonomi regional berbasis potensi daerah sehingga mampu menyerap tenaga kerja dan meningkatkan kualitas sumber daya manusia;

b. Meningkatkan daya saing global Jawa Barat dalam rangka mendorong percepatan pertumbuhan investasi;

c. Meningkatkan pelayanan kepada masyarakat di bidang transportasi udara.

Berikut adalah penjelasan secara umum mengenai bandara Kertajati di Majalengka, Jawa Barat:

Tabel 1. Gambaran Umum Bandara Kertajati

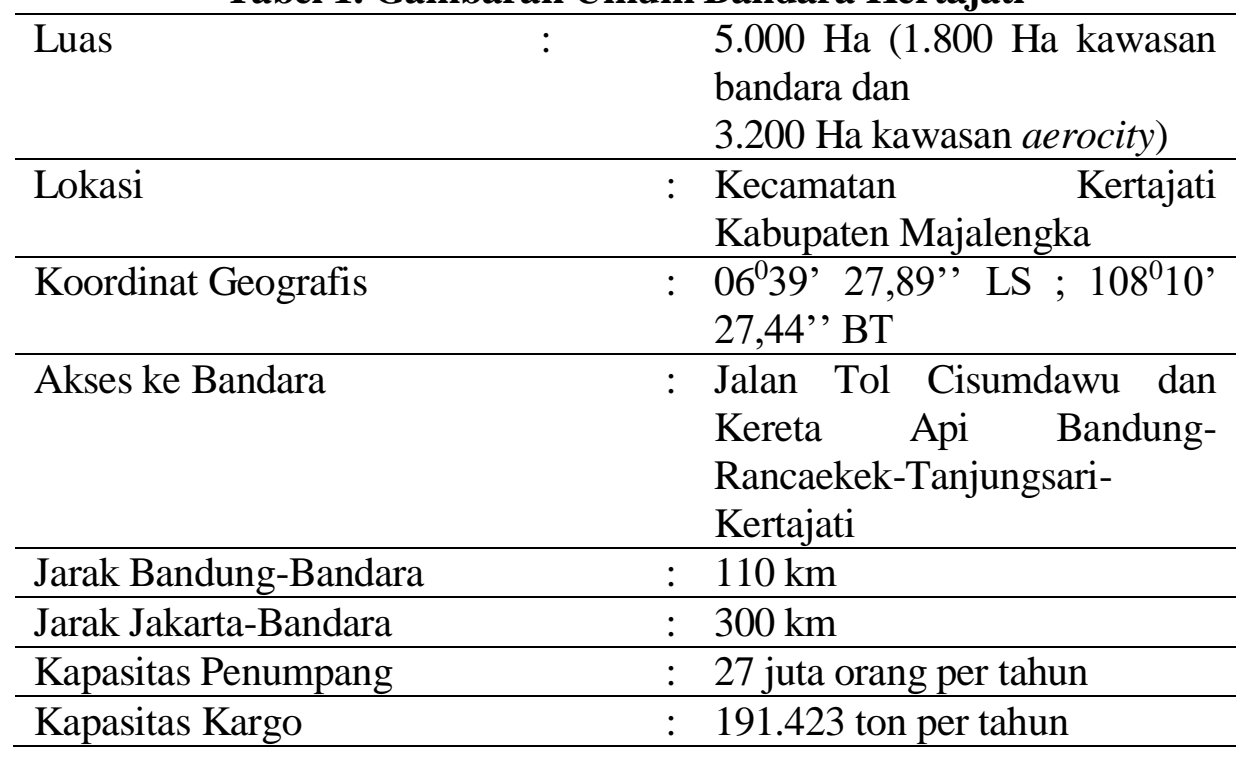




\begin{tabular}{ll}
\hline Total Biaya & : Rp8.299 M \\
\hline Sumber:Bappeda Provinsi Jawa Barat &
\end{tabular}

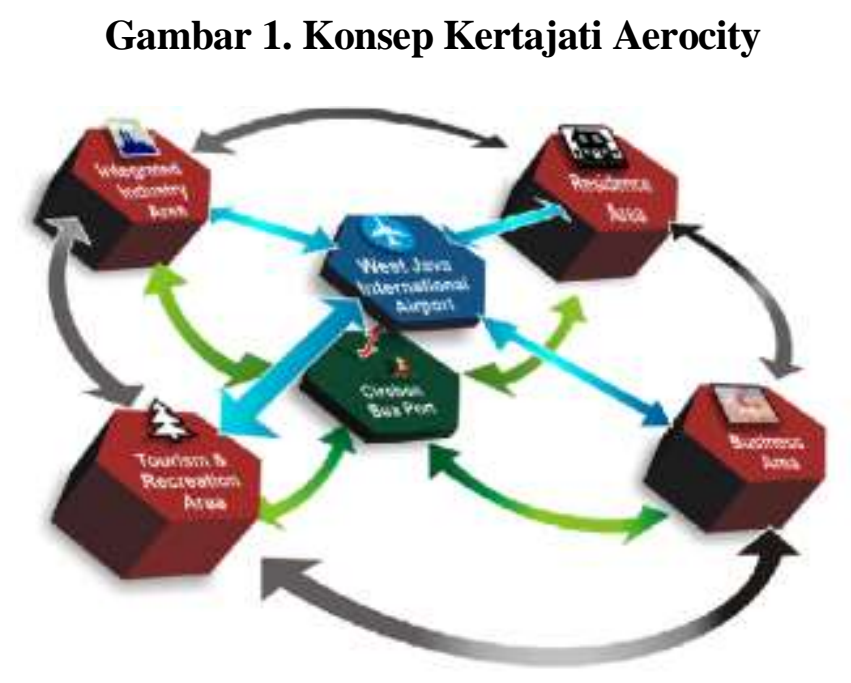

\section{Landasan Hukum}

Penyelenggaraan bandara tidak terlepas dari peraturan perundang-undangan dalam tingkat regional kawasan provinsi dan nasional. Landasan hukum yang terkait dengan penyelenggaraan bandara Kertajati dapat dilihat sebagai berikut:

a. Undang-undang No. 25 Tahun 2004 tentang Sistem Perencanaan Pembangunan Nasional;

b. Peraturan Daerah No. 6 Tahun 2009 tentang Sistem Perencanaan Pembangunan Daerah Jawa Barat;

c. Undang-undang No. 17 Tahun 2007 tentang Rencana Pembangunan Jangka Panjang Nasional Tahun 2005-2025;

d. Peraturan Presiden No. 5 Tahun 2010 tentang Rencana Pembangunan Jangka Menengah Nasional Tahun 2010 - 2014;

e. Peraturan Daerah Provinsi Jawa Barat No.13 Tahun 2010 tentang Pembangunan dan Pengembangan Bandar Udara Internasional Jawa Barat dan Kertajati Aerocity;

f. Peraturan Daerah Provinsi Jawa Barat No.22 Tahun 2013 tentang Pembentukan Badan Usaha Milik Daerah Pengelola Bandar Udara Internasional Jawa Barat dan Kertajati Aerocity;

g. Peraturan Menteri Perhubungan KM No. 5 Tahun 2007 tentang Rencana Induk Bandar Udara di Kabupaten Majalengka Provinsi Jawa Barat.

\section{Kerangka Kebijakan}

Sinergitas antara RPJMN 2010-2014, RPJMD Jawa Barat, Inpres No.3 Tahun 2010 dan Tujuan Pembangunan Millenium Development Goals sesuai Gambar 2. 


\section{Gambar 2. Sinergitas Kerangka Kebijakan}

\begin{tabular}{|c|c|c|}
\hline RPJMN 2010 - 2014 & $\begin{array}{l}\text { RPJMD JAWA BARAT } \\
2013-2018\end{array}$ & $\begin{array}{c}\text { INPRES NOMOR } 3 \text { TAHUN } 2010 \\
(4 \mathrm{P})\end{array}$ \\
\hline $\begin{array}{l}\text { 1. Prioritas 1, Reformasi Birokrasi } \\
\text { dan Tata Kelola } \\
\text { 2. Prioritas 2, Pendidikan } \\
\text { 3. Prioritas 3, Kesehatan } \\
\text { 4. Prioritas 4, Penanggulangan } \\
\text { Kemiskinan; } \\
\text { 5. Prioritas 5, Ketahanan Pangan; } \\
\text { 6. Prioritas 6, Infrastruktur; } \\
\text { 7. Prioritas 7, Iklim Investasi dan } \\
\text { Iklim Usaha; } \\
\text { 8. Prioritas } 8 \text {, Energi; } \\
\text { 9. Prioritas } 9 \text {, Lingkungan Hidup dan } \\
\text { Pengelolaan Bencana; } \\
\text { 10.Prioritas 10, Daerah Tertinggal, } \\
\text { Terdepan, Terluar dan Pasca } \\
\text { Konflik; } \\
\text { 11.Prioritas } 11 \text {, Kebudayaan, } \\
\text { Kreativitas dan Inovasi Teknologi; } \\
\text { 12.Prioritas 12, Bidang Politik, Hukum } \\
\text { dan Keamanan; } \\
\text { 13.Prioritas 13, Bidang Perekonomian; } \\
\text { 14.Prioritas 14, Bidang Kesejahteraan } \\
\text { Rakyat; }\end{array}$ & 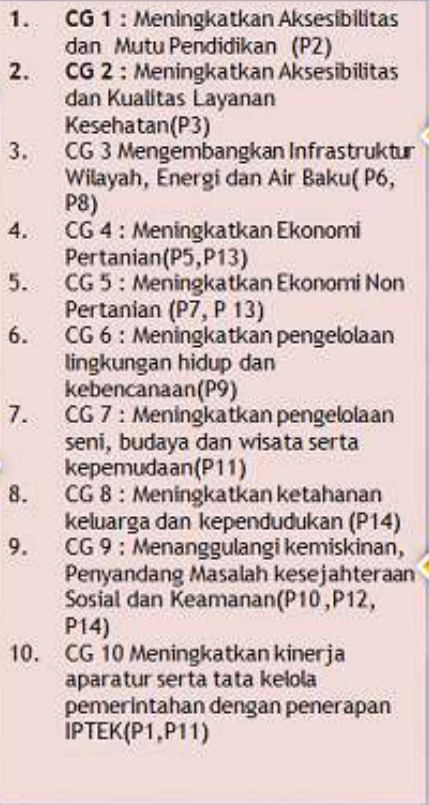 & 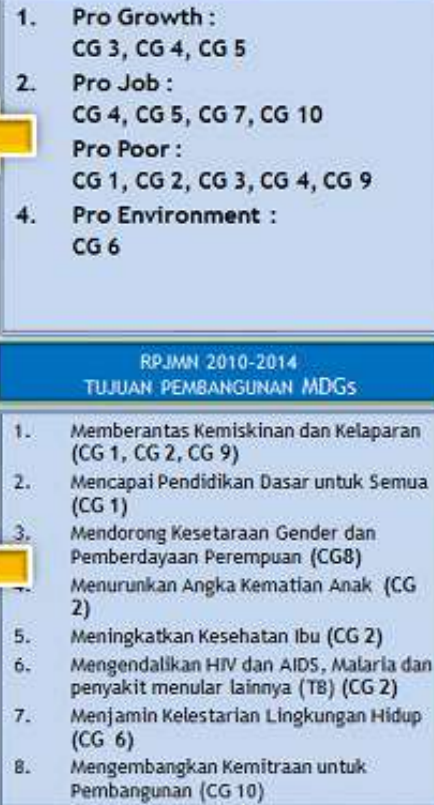 \\
\hline
\end{tabular}

Sumber:Bappeda Pemerintah Provinsi Jawa Barat

\section{Risiko Proyek}

Kemungkinan risiko yang terjadi berdasarkan kelompok risiko dari John D. Finnerty; Project Financing (Asset Based Financial Engineering, $2^{\text {nd }}$ Edition); adalah sebagai berikut:

a. Completion Risk

Jadwal penyelesaian pelaksanaan pembangunan bandara semula diperkirakanpada bulan Agustus 2017 namun terdapat kendala dari aspek moneter dimanabelum terdapatnya kejelasan pendanaan.

b. Financial Risk

Risiko terkait unsur-unsur makro ekonomi seperti besar tingkat suku bunga dan inflasi. Tingkat suku bunga merupakan variabel yang fluktuatif dan untuk mengurangi risiko pembiayaan dapat dilakukan hedging.

c. Enviromental Risk

Relokasi warga belum dapat dilakukan karena belum adanya kesepakatan antara pemerintah dengan warga sehingga terdapat lahan rencana yang belum dibebaskan seluas $54 \mathrm{Ha}$ di Desa Sukakerta dan Desa Sukamulya Kecamatan Kertajati.

d. Political Risk

Pembangunan bandara Kertajati telah sesuai dengan kebijakan RPJMND namun risiko terkait persetujuan penganggaran pada APBD di masa mendatang oleh legislatif dapat berubah untuk pendanaan infrastruktur prioritas lainnya.

e. Force Majeure Risk 
Force majeure dapat terjadi dari internal proyek (kebakaran, kegagalan teknis) dan eksternal proyek (gempa bumi, banjir) dimana keduanya berdampak siginifikan terhadap proyek.BNPB mencatat Indeks Rawan Bencana Kabupaten Majalengka di rangking 16 dalam skala nasional dan di rangking 7 dalam Provinsi Jawa Barat. Angka tersebut menunjukkan kerawanan Kabupaten Majalengka terhadap bencana alam dan risiko force majeur harus diperhitungkan dalam perencanaan.

\section{Stakeholder}

Stakeholder meliputi proses mengidentifikasi orang, kelompok atau organisasi yang memberikan dampak atau terkena dampak oleh pelaksanaan proyek.Pihakpihak yang terlibat dalam pelaksanaan pembangunan Bandara Kertajati dapat dilihat pada Tabel 2.

Tabel 2. Stakeholder Proyek Bandara Kertajati

\begin{tabular}{|c|c|c|}
\hline No & Stakeholder & Keterangan \\
\hline 1 & $\begin{array}{lr}\text { Direktorat } & \text { Jenderal } \\
\text { Perhubungan } & \text { Udara } \\
\text { Kementerian Perhubungan }\end{array}$ & Pemberi izin pendirian terminal bandara \\
\hline 2 & $\begin{array}{l}\text { Pemerintah Provinsi Jawa } \\
\text { Barat }\end{array}$ & Pemilik aset daerah Bandara Kertajati \\
\hline 3 & $\begin{array}{l}\text { Pemerintah Kabupaten } \\
\text { Majalengka }\end{array}$ & Pemilik aset daerah Bandara Kertajati \\
\hline 4 & $\begin{array}{lll}\text { Bappeda } & \text { Provinsi Jawa } \\
\text { Barat } & & \\
\end{array}$ & $\begin{array}{l}\text { Instansi penyusun rencana dan strategis } \\
\text { daerah }\end{array}$ \\
\hline 5 & PT. Angkasa Pura II & BUMN Pengelola Bandara Kertajati \\
\hline 6 & $\begin{array}{l}\text { PT. Bandar Udara } \\
\text { Internasional Jawa Barat }\end{array}$ & BUMD Pengelola Bandara Kertajati \\
\hline 7 & PT. Penta Arsitektur & Konsultan Perencana Bangunan Terminal \\
\hline 8 & PT. Jakarta Konsultindo & $\begin{array}{l}\text { Konsultan Perencana Penyusunan Rencana } \\
\text { Induk Kawasan Bandara }\end{array}$ \\
\hline 9 & $\begin{array}{l}\text { PT.Billitonica Indomatra } \\
\text { Consultant }\end{array}$ & $\begin{array}{l}\text { Konsultan Pengawas Fasilitas Sisi Udara } \\
\text { Tahap II }\end{array}$ \\
\hline 10 & PT. Waskita Karya & $\begin{array}{ll}\text { Kontraktor Pelaksana } & \mathrm{Pe} \\
\text { Fasilitas Airside } & \text { Bandara }\end{array}$ \\
\hline & Masyarakat sekitar bandara & $\begin{array}{l}\text { Pihak yang terkena dampak pembangunan } \\
\text { bandara }\end{array}$ \\
\hline
\end{tabular}

Sumber:Data Diolah

\section{Pembiayaan}

Pelaksanaan pembiayaan pembangunan Bandara Kertajati semula direncanakan dengan sistem Kerja Sama Pemerintah Swasta (KPS) dimana sudah terdapat \pm 40 investor potensial yang berminat namun belum ada yang terealisasi sampai dengan saat ini. Pembiayaan dilakukan oleh pemerintah pusat dan daerahdimana pembangunan sisi udara yang terdiri dari runway, taxiway, apron, Air Traffic Controller (ATC) dibebankan pada APBN dan sisi darat yang terdiri dari pembebasan lahan dan pembangunan terminal dibebankan pada APBD provinsi dan kabupaten.Pembangunan Bandara Kertajati diperkirakan membutuhkan 
biaya sebesar Rp8.299 Milyar (Hasil Evaluasi Pencapaian Proyek Infrastruktur 2011 s.d. 2013; MP3EI, Sekretariat Koridor Jawa) diluar pembebasan lahan.

Tabel 3. Pembiayaan Proyek Bandara Kertajati

\begin{tabular}{|c|c|c|c|}
\hline Sumber & Tahun & Nilai (Rp) & Keterangan \\
\hline APBD & $\begin{array}{l}2009- \\
2012\end{array}$ & $293 \mathrm{M}$ & $\begin{array}{l}\text { pembebasan lahan seluas } 464 \\
\mathrm{Ha}\end{array}$ \\
\hline APBD & 2013 & $378 \mathrm{M}$ & $\begin{array}{l}\text { pembebasan lahan seluas } 502 \\
\text { Ha }\end{array}$ \\
\hline APBD & 2014 & $200 \mathrm{M}$ & $\begin{array}{l}\text { pembebasan lahan seluas } 400 \\
\text { Ha }\end{array}$ \\
\hline APBN & 2012 & $100 \mathrm{M}$ & \multirow{3}{*}{$\begin{array}{l}\text { pembangunan runway } \\
\text { sepanjang } 2.500 \mathrm{~m} \text { dan lebar } \\
60 \mathrm{~m}\end{array}$} \\
\hline APBN & 2013 & $130 \mathrm{M}$ & \\
\hline APBN & 2014 & $85 \mathrm{M}$ & \\
\hline
\end{tabular}

Sumber: Data Diolah

Progres proyek pada September 2014 menunjukkan bahwa lahan yang telah dibebaskan sebesar1.366Ha dan pembangunan fasilitas yang sedang dikerjakan adalah runway $2.500 \times 60 \mathrm{~m}$ sementara pembangunan fasilitas lainnya dilakukan secara bertahap mengacu pada pertumbuhan penumpang yang diperkirakan antara 6-12 juta orang per tahun serta terdapatnya ketersediaan dana. Entity:

Special Purpose Vehiclel Special Purpose Company/ Special Purpose

Special Purpose Vehicle (SPV) merupakan lembaga ad hocyang dibentuk untuk menangani proyek dengan skema pembiayaan KPS. Proyek pembangunan Bandara Kertajati belum memiiki SPV karena belum terdapatnya skema pembiayaan KPS. Pembiayaan untuk pembebasan lahan dan pembangunan runway yang saat ini sudah dilakukan berasal dari APBN dan APBD provinsi serta kabupaten.

\section{PENUTUP}

Berdasarkan hasil pembahasan, maka dapat disimpulkan sebagai berikut.

1. Kertajati adalah salah satu proyek nasional yang kita harapkan sudah jadi paling lambat pertengahan 2018. Bisa digunakan untuk pesawat kelas 747 dan 777, salah satunya untuk memenuhi pangsa besar di Jawa barat yaitu kegiatan Umroh. Kalau sekarang kan kasihan, jamaah umroh dari Jawa Barat dan sekitarnya harus memakan waktu yang cukup lama untuk menuju bandara Soekarno Hatta.

2. Bandara Kertajati di Majalengka diproyeksikan menjadi pusat layanan logistik untuk Jawa Barat dan Jawa Tengah. Untuk mewujudkannya, pemerintah mendorong penyelesaian pembangunan jalan tol ke bandara itu. Kita akan mendorong pembangunan jalan tol Cisumdawu dan koneksinya ke jalan tol Cipali yang menjadi akses penopang menuju bandara ini. 


\section{Daftar Pustaka}

Agustino, Leo. 2006. Politik dan Kebijakan Publik. Bandung: AIPIKP2W Lemlit Unpad

http://industri.bisnis.com/read/20170804/98/677992/kepemilikan-bandarakertajati-jabar-bertahan-mayoritas

https://finance.detik.com/berita-ekonomi-bisnis/3585137/proyek-bandarakertajati-terus-dikebut-begini-progresnya

http://dephub.go.id/post/read/pastikan-selesai-sesuai-target,-menhub-tinjauproyek-pembangunan-bandara-kertajati

http://bandung.bisnis.com/read/20120927/6/244738/bandara-kertajati-skemapembangunan-kps-dimatangkan

http://aksi.id/artikel/18485/Progres-Pembangunan-Bandara-Kertajati-Hampir-70/

Rencana Kerja Pemerintah Daerah Provinsi Jawa Barat Tahun 2018

Anderson, James E. 1978. Public Policy Making. Holt, Rinehart and Winston.

Bappeda Provinsi Jawa Barat: 2003. Rencana Tata Ruang Wilayah Provinsi Jawa Barat 2010.

Danim, Sudawan, 1997. Pengantar Studi Penelitian Kebijakan,Jakarta: Bumi Aksara.

Dunn, William N, 2000. Analisis Kebijakan Publik. Yogyakarta:Gadjah Mada Press.

Edwards III, G.C. 1980. Implementing Public Policy. Washington:Congressional Quarterly Press.

Garna, Judistira K. 1999. Metode Penelitian Pendekatan Kualitatif.Bandung : Primaco Akademika.

Grindle, M.S. 1980. Politics and Policy Implementation in The Third World. New Jersey: Princeton University Press.

Harsono, Boedi. 2000. Hukum Agraria di Indonesia: Himpunan PeraturanPeratutan Hukum Tanah. Jakarta: Djambatan.

Hogwood, Brian W., \& Lewis A. Gunn. 1984. Policy Analysis for The Real World. New York: Oxford Univrsity Press.

Hook, S. 1980. Philosophy and Public Policy. Southern Illinois Press, Feffer \& Simon, Inc.

Islamy, M. Irfan, 2000. Prinsip-prinsip Perumusan Kebijakan Negara. Jakarta: Bina Aksara

Mazmanian, D.A. \& Paul A. Sabatier. 1983. Implementation and Public Policy. London: Scott, Foresman and Company.

Moeljarto, T. 1995. Politik Pembangunan. Yokyakarta: PT Tiara Wacana Yogya.

Moeleong, Lexy. J. 2000. Metode Penelitian Kualitatif. Bandung: PT Remaja Rosda Karya.

PT Remaja Rosda Karya.

Murad, Rusmadi. 1997. Administrasi Pertanahan: Pelaksanaannya dalam Praktek. Bandung: Penerbit Mandar Maju

Nazir, Mohammad. 1998. Metode Penelitian. Jakarta: Ghalia Indonesia.

Peraturan Presiden Nomor 36 Tahun 2005 tentang Pengadaan Tanah Bagi Pelaksanaan Pembangunan Untuk Kepentingan Umum dan Peraturan 
AKSARA: Jurnal Ilmu Pendidikan Nonformal

P-ISSN $\underline{2407-8018}$ E-ISSN $\underline{2721-7310}$ DOI prefix $\underline{10.37905}$

Volume 07 (02) Mei 2021

http://ejurnal.pps.ungac.id/index.php/Aksara

Presiden Nomor 65 Tahun 2006 tentang Perubahan atas Peraturan Presiden Nomor 36 Tahun 